\title{
EFFECT OF LATE SEEDING WARMER CONDITION ON PHENOLOGY AND YIELD OF WHEAT
}

\author{
S. Sharmin, M.A. Hasan and S. Sikder \\ Department of Crop Physiology and Ecology, Hajee Mohammad Danesh Science and Technology University, \\ Dinajpur 5200, Bangladesh \\ Corresponding E-mail: seulisharminhstu@gmail.com
}

(Received: 11 December 2020, Accepted: 10 January 2021)

Keywords: Cell membrane thermostability, heat susceptibility index, phenology, yield, wheat

\begin{abstract}
Four wheat variety/genotype (BARI Gom-26, BAW-1202, BAW-1182 and BARI Gom-27) were tested under three heat stress regimes (normal, moderate and severe) to evaluate the effect of late seeding warmer condition on phenology and yield of wheat, as well as to identify suitable cultivars to develop heat-tolerant genotypes at Hajee Mohammad Danesh Science and Technology University (HSTU), Dinajpur during November, 2016 to April, 2017. Results revealed that genotype BAW-1182 and BAW-1202 showed greater thermostability of cell membrane with acceptable yield performance under heat stress condition. The order of tolerance based on heat susceptibility index (based on grain yield) was BAW-1182>BAW-1202>BARI Gom27>BARI Gom-26 under heat stress conditions. Thus, BAW-1182 and BAW-1202 have the greatest potential to be used as high-yielding wheat genotypes under warm to hot environments and could be used in a breeding programme to develop heattolerant wheat.
\end{abstract}

\section{Introduction}

Wheat (Triticum aestivum L.) is an important cereal crop ranking number one globally and number two in Bangladesh both in terms of production and acreage. Generally, wheat is sown in mid-November to ensure optimal crop growth and avoid high-temperature stress. However, about $60 \%$ of the wheat is cultivated in late sowing conditions after harvesting the transplanted aman rice (Baharuddin et al., 1994). An important limitation to wheat productivity is the heat stress that affects different growth stages, specially anthesis and grain filling as evident from late sowing (Din et al., 2010). Despite the low yield of wheat due to terminal heat stress, its cultivation cannot be avoided totally. The adverse effect of temperature can be minimized by breeding heat-tolerant genotypes that could be sown late with a high grain yield. In this context, this study aimed to evaluate the effect of late seeding warmer condition on phenology and yield of wheat genotypes followed by screening high-temperature stress-tolerant traits of wheat genotypes in the breeding program.

\section{Materials and Methods}

The experiment was set up at Hajee Mohammad Danesh Science and Technology University (HSTU), Dinajpur during November, 2016 to April, 2017. The experimental site was situated

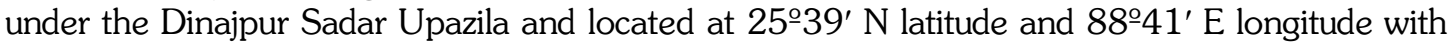
an elevation of 37.58 meter above sea level. The experimental field was a medium high land 
belonging to the Non calcareous Dark Grey Floodplain soil under the Agro-ecological Zone (AEZ-1) of the Old Himalayan Piedmont Plain. Three growing conditions -normal sowing in November 20, moderate heat stress sowing in December 20 and severe heat stress sowing in January 10 were placed in the main plots whereas four wheat variety/genotypes: BARI Gom26, BAW-1202, BAW-1182 and BARI Gom-27 were placed in sub-plots following split-plot design. Seeds were sown in rows of $20 \mathrm{~cm}$ apart, at the rate of $120 \mathrm{~kg} \mathrm{ha}^{-1}$. A fertilizer dose of 140-35-75-18-2-0.5 kg ha-1 N, P, K, S, Zn and B was applied following fertilizer recommendation.

Phenological stages like anthesis, physiological maturity were observed and recorded in days when $50 \%$ of plants of each plot reached a definite stage (Zadoks et al., 1974). Cell membrane thermostability test was done as described by Blum and Ebercon (1981). Heat susceptibility index (S) was calculated for yield as following Fischer and Maurer (1978). Data were collected on yield and yield contributing characters of wheat. The data were analyzed by partitioning the total variance with the help of a computer using the MSTATC program. The treatment means were compared using Tukey's test at a 5\% level of significance.

\section{Results and Discussion}

Late sown (20 December and 10 January sown) wheat genotypes exposed to heat stress $\left(>20^{\circ} \mathrm{C}\right)$ during most of their reproductive growth phase but the wheat genotypes sown on 20 November experienced more or less $20^{\circ} \mathrm{C}$ temperature throughout their whole reproductive growth phase and considered as normal growing condition (Fig. 1). The optimum temperature for wheat crop growth is about $20^{\circ} \mathrm{C}$ (Al-Khatib and Paulsen, 1984). Temperature in the range of 20 to $25^{\circ} \mathrm{C}$ has been considered favorable for wheat seed germination, seedling emergence and optimum plant establishment (Behl et al., 1993).

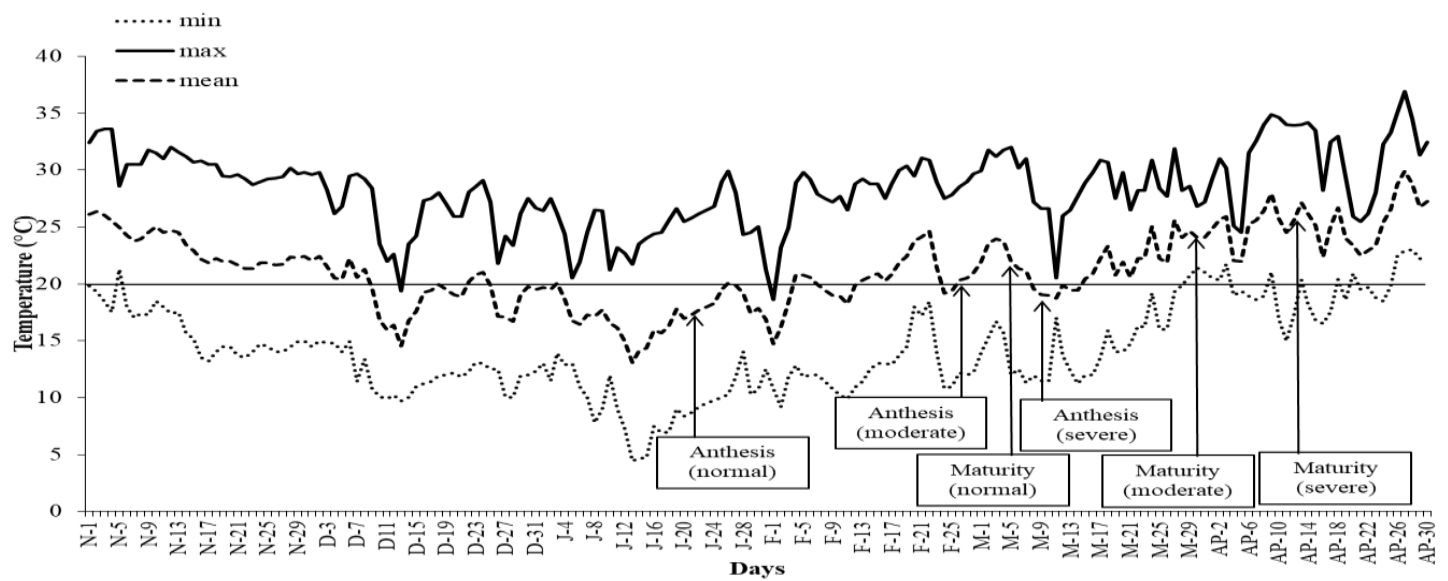

Fig. 1. Maximum, minimum and mean air temperature from 01 November 2016 to 30 April 2017 showing the period of anthesis and maturity of normal, moderate heat stress and severe heat stress.

\section{Phenology}

\section{Days to anthesis}

Days required to anthesis were significantly influenced by the interaction effect of growing conditions and wheat genotypes (Table 1). Under the normal growing condition, BAW-1182 
required the highest number of days (73 days) for anthesis which was followed by BARI Gom-27 (72 days) and BARI Gom-26 (72 days) whereas BAW-1202 required the lowest number of days (66 days) for anthesis. Due to late seeding warmer conditions (both at moderate and severe heat stress conditions) anthesis occurred earlier than normal growing condition in all the wheat genotypes except in BAW-1202 at moderate heat stress condition. But earliness of anthesis due to heat stress conditions (both at moderate and severe heat stress conditions) were not similar for all wheat genotypes at moderate and severe heat stress conditions. Delay in sowing (both at moderate and severe heat stress conditions) decreased the number of days required to anthesis. Days to anthesis required a lower number of days under heat stress conditions and similar results were found by Dias et al. (2009) and Nahar et al. (2010).

Table 1. Effect of late seeding warmer condition and wheat genotypes on days to anthesis

\begin{tabular}{|c|c|c|c|}
\hline \multirow{3}{*}{ Genotypes } & \multicolumn{3}{|c|}{ Days to anthesis (days) } \\
\hline & \multicolumn{3}{|c|}{ Growing conditions } \\
\hline & Normal & Moderate heat stress & Severe heat stress \\
\hline V1 (BARI Gom-26) & $72 \mathrm{ab}$ & $69 \mathrm{bc}$ & $60 \mathrm{~d}$ \\
\hline V2 (BAW-1202) & $66 c$ & $69 \mathrm{bc}$ & $59 \mathrm{~d}$ \\
\hline V3 (BAW-1182) & $73 \mathrm{a}$ & $69 \mathrm{bc}$ & $62 \mathrm{~d}$ \\
\hline V4 (BARI Gom-27) & $72 a b$ & $70 \mathrm{ab}$ & $60 \mathrm{~d}$ \\
\hline Level of Significance & \multicolumn{3}{|c|}{ *** } \\
\hline CV (\%) & \multicolumn{3}{|c|}{1.65} \\
\hline
\end{tabular}

Means followed by the same letter(s) did not differ significantly at 5\% level by MSTATC program. ** Significant at the $1 \%$ probability level

\section{Physiological maturity}

Days required to physiological maturity were significantly influenced by the interaction effect of growing conditions and wheat genotypes (Table 2). Under the normal growing condition, BARI Gom-26, BAW-1182 and BARI Gom-27 required the highest number of days (106 days) for physiological maturity whereas BAW-1202 required the lowest number of days (100 days) for physiological maturity. Due to late seeding warmer conditions (both at moderate and severe heat stress conditions) physiological maturity occurred earlier compared to the normal growing condition in all the wheat genotypes. But earliness of anthesis due to heat stress conditions (both at moderate and severe heat stress conditions) were not similar for all wheat genotypes. Hossain et al. (2011, 2012a) and Hakim et al. (2012) also found that the duration of maturity of spring wheat genotypes reduced by high temperature stress in northern Bangladesh. The increasing temperature during grain tended to stop grain growth prematurely and to hasten physiological maturity. A similar result was found by Amrawat et al. (2013).

Table 2. Effect of late seeding warmer condition and wheat genotypes on physiological maturity

\begin{tabular}{|c|c|c|c|}
\hline \multirow{3}{*}{ Genotypes } & \multicolumn{3}{|c|}{ Physiological maturity (days) } \\
\hline & \multicolumn{3}{|c|}{ Growing conditions } \\
\hline & Normal & Moderate heat stress & Severe heat stress \\
\hline BARI Gom-26 & $106 a$ & $100 \mathrm{~b}$ & $95 \mathrm{c}$ \\
\hline BAW-1202 & $100 \mathrm{~b}$ & $96 c$ & $90 \mathrm{~d}$ \\
\hline BAW-1182 & $106 \mathrm{a}$ & $102 \mathrm{~b}$ & $95 \mathrm{c}$ \\
\hline BARI Gom-27 & $106 a$ & $102 b$ & $90 \mathrm{~d}$ \\
\hline Level of Significance & \multirow{2}{*}{\multicolumn{3}{|c|}{$\begin{array}{c}* * * \\
0.88\end{array}$}} \\
\hline CV $(\%)$ & & & \\
\hline
\end{tabular}

Means followed by the same letter(s) did not differ significantly at 5\% level by MSTATC program. ** Significant at the $1 \%$ probability level 


\section{Cell membrane thermostability}

Cell membrane thermostability (CMT) of flag leaf at 18 days after anthesis differed among the wheat genotypes tested (Fig. 2). The highest cell membrane thermostability was found in BAW1202 (53.8\%) which was followed by BARI Gom-26 (53.1\%). On the other hand, BAW-1182 (42.8\%) showed moderate cell membrane thermostability and BARI Gom-27 (29.7\%) showed the lowest cell membrane thermostability. The results indicated that the wheat genotypes BAW1202 and BARI Gom-26 were more tolerant against heat stress conditions than BAW-1182 and BARI Gom-27. Genotypic differences in membrane injury of flag leaf at anthesis of the fieldgrown wheat were also reported by Hasan et al. (2007) and Mohi-Ud-Din et al. (2007).

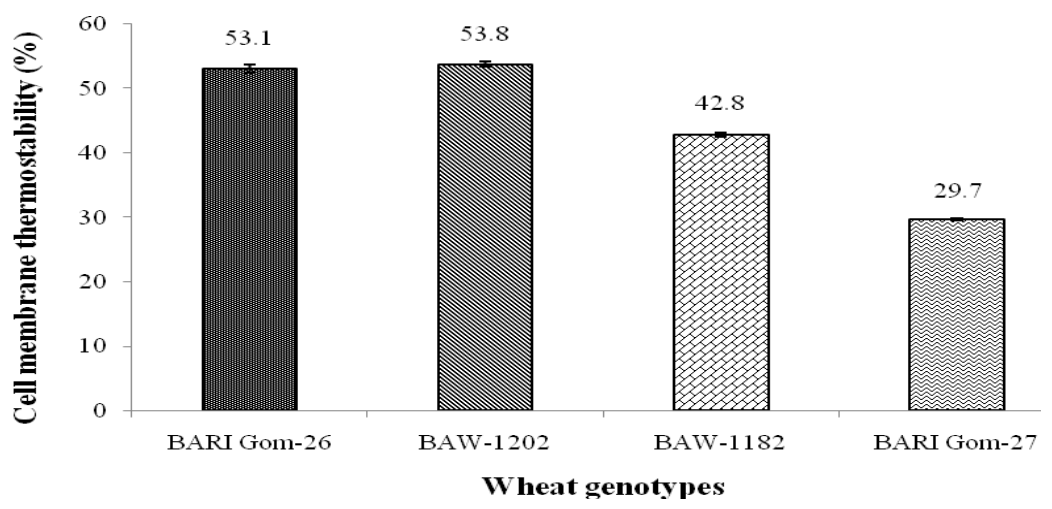

Fig. 2. Cell membrane thermostability of different wheat genotypes at 18 days after anthesis.

\section{Tillers $\mathrm{m}^{-2}$}

Tillers per $\mathrm{m}^{2}$ of four wheat genotypes at different growing conditions are presented in Table 3. Results showed that the interaction effect of growing conditions and wheat genotypes on tillers $\mathrm{m}^{-2}$ was significant. Under the normal growing condition, BAW-1202 showed the maximum tillers $\mathrm{m}^{-2}$ (332.3) which was statistically similar to BARI Gom-27 (320.2). Genotype BAW-1182 (275.3) showed the lowest number of tillers $\mathrm{m}^{-2}$ which was statistically similar to BARI Gom-26 (273.0). Under moderate heat stress condition, BARI Gom-27 showed the highest tillers $\mathrm{m}^{-2}$ (336.3). BAW-1182 showed moderate (296.7) which was statistically similar to BAW- 1202 (278.8). BARI Gom-26 showed the lowest tillers $\mathrm{m}^{-2}$ (226.3). Under severe heat stress condition, BARI Gom-27 showed the maximum tillers $\mathrm{m}^{-2}$ (215.8) which was statistically similar to BAW-1202 (214.5). Genotype BAW-1182 (179.0) showed moderate tillers $\mathrm{m}^{-2}$ and lowest in BARI Gom-26 (107.7).

Table 3. Effect of late seeding warmer condition and wheat genotypes on tillers $\mathrm{m}^{-2}$

\begin{tabular}{|c|c|c|c|}
\hline \multirow{3}{*}{ Genotypes } & \multicolumn{3}{|c|}{ Tillers $\mathrm{m}^{-2}$ (no.) } \\
\hline & \multicolumn{3}{|c|}{ Growing conditions } \\
\hline & Normal & Moderate heat stress & Severe heat stress \\
\hline BARI Gom-26 & $273.0 c$ & $226.3 \mathrm{~d}$ & $107.7 \mathrm{f}$ \\
\hline BAW-1202 & $332.3 \mathrm{a}$ & $278.8 c$ & $214.5 \mathrm{~d}$ \\
\hline BAW-1182 & $275.3 c$ & 296.7 bc & $179.0 e$ \\
\hline BARI Gom-27 & $320.2 \mathrm{ab}$ & $336.3 \mathrm{a}$ & $215.8 \mathrm{~d}$ \\
\hline Level of Significance & \multicolumn{3}{|c|}{$* *$} \\
\hline CV $(\%)$ & \multicolumn{3}{|c|}{4.33} \\
\hline
\end{tabular}

Means followed by the same letter(s) did not differ significantly at the 5\% level by the MSTATC program.

** Significant at the $1 \%$ probability level 


\section{Spikes $\mathrm{m}^{-2}$}

Spikes per $\mathrm{m}^{2}$ of four wheat genotypes at different growing conditions are presented in Table 4. Results showed that the interaction effect of growing conditions and wheat genotypes on spikes $\mathrm{m}^{-2}$ was significant. Under the normal growing condition, BAW-1202 showed the maximum spikes $\mathrm{m}^{-2}$ (327.5) which was statistically similar to BARI Gom-27 (315.8). Genotype BAW1182 (268.3) showed the lowest number of spikes $\mathrm{m}^{-2}$ which was statistically similar to BARI Gom-26 (270.0). Under moderate heat stress conditions, BARI Gom-27 showed the highest spikes $\mathrm{m}^{-2}$ (327.2). Genotype BAW-1182 showed moderate (290.3), which was statistically similar to BAW-1202 (272.5). BARI Gom-26 showed the lowest spikes $\mathrm{m}^{-2}$ (239.5), which was also statistically similar to BAW-1202 (272.5). Under severe heat stress conditions, BARI Gom26 showed the maximum spikes $\mathrm{m}^{-2}$ (240.7) which was statistically similar to BAW-1202 (209.8). Genotype BAW-1182 showed the lowest spikes $\mathrm{m}^{-2}$ (174.8), which was statistically similar to BARI Gom-27 (176.7). BARI Gom-27 is also statistically similar to BAW-1202. Results from other studies showed that spike number plant ${ }^{-1}$ was not significantly influenced by late sowing (Hasan et al., 2007). Hu and Rajaram (1994) reported that spike number plant ${ }^{-1}$ was less sensitive while the yield, grains spike $e^{-1}$, biomass and plant height were more sensitive to high temperature.

Table 4. Effect of late seeding warmer condition and wheat genotypes on spikes $\mathrm{m}^{-2}$

\begin{tabular}{lccc}
\hline \multirow{2}{*}{ Genotypes } & \multicolumn{3}{c}{ Spikes $\mathrm{m}^{-2}$ (no.) } \\
\cline { 2 - 4 } & Normal & Moderate heat stress & Severe heat stress \\
\cline { 2 - 4 } & $270.0 \mathrm{~cd}$ & $239.5 \mathrm{de}$ & $240.7 \mathrm{de}$ \\
BARI Gom-26 & $327.5 \mathrm{a}$ & $272.5 \mathrm{~cd}$ & $209.8 \mathrm{ef}$ \\
BAW-1202 & $268.3 \mathrm{~cd}$ & $290.3 \mathrm{bc}$ & $174.8 \mathrm{~g}$ \\
BAW-1182 & $315.8 \mathrm{ab}$ & $327.2 \mathrm{a}$ & $176.7 \mathrm{fg}$ \\
BARI Gom-27 & & $* * *$ \\
\hline Level of Significance & & 4.21 & \\
CV (\%) & & & \\
\hline
\end{tabular}

Means followed by the same letter(s) did not differ significantly at $5 \%$ level by MSTATC program. ** Significant at the $1 \%$ probability level

\section{Spikelets spike $e^{-1}$}

Spikelets spike ${ }^{-1}$ of four wheat genotypes at different growing conditions is presented in Table 5 . Results showed that the interaction effect of growing conditions and wheat genotypes on spikelets spike ${ }^{-1}$ was significant.

Table 5. Effect of late seeding warmer condition and wheat genotypes on spikelets spike-1

\begin{tabular}{|c|c|c|c|}
\hline \multirow{3}{*}{ Genotypes } & \multicolumn{3}{|c|}{ Spikelets spike ${ }^{-1}$ (no.) } \\
\hline & \multicolumn{3}{|c|}{ Growing conditions } \\
\hline & Normal & Moderate heat stress & Severe heat stress \\
\hline BARI Gom-26 & $18.83 \mathrm{bcd}$ & $21.47 \mathrm{a}$ & $18.30 \mathrm{bcd}$ \\
\hline BAW-1202 & $17.57 \mathrm{~d}$ & $20.00 \mathrm{ab}$ & $18.23 \mathrm{bcd}$ \\
\hline BAW-1182 & $19.07 \mathrm{bcd}$ & $21.67 \mathrm{a}$ & $19.43 \mathrm{bc}$ \\
\hline BARI Gom-27 & $18.13 \mathrm{~cd}$ & $18.53 \mathrm{bcd}$ & $17.30 \mathrm{~d}$ \\
\hline Level of Significance & \multicolumn{3}{|c|}{$*$} \\
\hline CV (\%) & \multicolumn{3}{|c|}{3.06} \\
\hline
\end{tabular}

Means followed by the same letter(s) did not differ significantly at the $5 \%$ level by the MSTATC program.

* Significant at the $5 \%$ probability level 
Under the normal growing condition, BAW-1182 showed the maximum number of spikelets spike $^{-1}$ (19.07), which was statistically similar to BARI Gom-26 (18.83), BARI Gom-27 (18.13) and BAW-1202 (17.57). Genotype BAW-1202 showed the lowest number of spikelets spike ${ }^{-1}$. Under moderate heat stress conditions, BAW-1182 showed the maximum number of spikelets spike $^{-1}$ (21.67) which was statistically similar to BARI Gom-26 (21.47) and BAW-1202 (20.00). BARI Gom-27 showed the lowest spikelets spike $e^{-1}$ (18.53), which was also statistically similar to BAW-1202 (20.00). Under severe heat stress condition, BAW-1182 showed the maximum number of spikelets spike $e^{-1}$ (19.43), which was statistically similar to BARI Gom-26 (18.30) and BAW-1202 (18.23). BARI Gom-27 showed the lowest (17.30) which was also statistically similar to BARI Gom-26 and BAW-1202.

\section{Grains spike $e^{-1}$}

Grains spike ${ }^{-1}$ at different growing conditions are presented in Table 6. From the results it was observed that grains per spike were significantly influenced by growing conditions. Irrespective of growing conditions, normal growing conditions showed the maximum grains spike $e^{-1}(50.20)$ which was statistically similar to moderate heat stress (49.14) whereas severe heat stress showed the lowest grains spike ${ }^{-1}(42.32)$. Due to heat stress, grains per spike were decreased in severe heat stress condition (15.70\%) and moderate heat stress condition (2.11\%). Sowing of seed at normal growing conditions may have enjoyed a longer duration and favorable temperature for growth and development as compared to others and produced a maximum number of grains spike $e^{-1}$. Heat stress, singly or in combination with drought, is a common constraint during anthesis and grain filling stages in many cereal crops of the temperate region (Nahar et al., 2010).

Grains spike $e^{-1}$ of four wheat genotypes are presented in Table 7. From the results it was observed that grains spike ${ }^{-1}$ were significantly influenced by wheat genotypes but the combined effect insignificant. In the case of variety /genotype, BARI Gom-26 had the highest grains spike $^{-1}$ (54.80) where BAW-1182 had a moderate number (49.00) which was statistically similar to BARI Gom-27 (44.30). Genotype BAW-1202 showed the lowest number of grains spike ${ }^{-1}$ (40.78) which was also statistically similar to BARI Gom-27. Significant differences among the genotypes for the number of grains spike ${ }^{-1}$ were found in wheat (Falaki et al., 2009) and it may be due to the variation in the genetic potential.

\section{Grain weight spike-1}

Grain weight spike-1 of four wheat genotypes at different growing conditions is presented in Table 6. Results showed that the interaction effect of growing conditions and wheat genotypes on grain weight spike ${ }^{-1}$ was significant. Under the normal growing conditions, BAW-1182 showed the maximum grain weight $(2.51 \mathrm{~g})$, which was statistically similar to BARI Gom-26 $(2.42 \mathrm{~g})$ and BARI Gom-27 (2.24 g). Genotype BAW-1202 showed the lowest grain weight $(2.14 \mathrm{~g})$ which was also statistically similar to BARI Gom-26 (2.42 g) and BARI Gom-27 $(2.24 \mathrm{~g})$. Under moderate heat stress conditions, BARI Gom-26 showed the highest grain weight $(2.69 \mathrm{~g})$ whereas BAW-1182 showed moderate weight $(2.21 \mathrm{~g})$ but similar to BAW-1202 $(2.16 \mathrm{~g})$. BARI Gom-27 showed the lowest grain weight $(1.60 \mathrm{~g})$. Under severe heat stress condition, BARI Gom-26 showed the maximum grain weight $(1.82 \mathrm{~g})$, which was statistically similar to BAW-1182 (1.68 g) and BAW-1202 (1.64 g). BARI Gom-27 showed the lowest grain weight $(1.25 \mathrm{~g})$. Significant variations were observed among the genotypes in the reduction of grain weight spike ${ }^{-1}$ under heat stress of 26 C mean temperature (Fokar et al., 1998). 
Table 6. Effect of late seeding warmer condition and wheat genotypes on grain wt. spike-1

\begin{tabular}{|c|c|c|c|}
\hline \multirow{3}{*}{ Genotypes } & \multicolumn{3}{|c|}{ Grain wt. spike $^{-1}(\mathrm{~g})$} \\
\hline & \multicolumn{3}{|c|}{ Growing conditions } \\
\hline & Normal & Moderate heat stress & Severe heat stress \\
\hline BARI Gom-26 & $2.42 \mathrm{abc}$ & $2.69 \mathrm{a}$ & $1.82 \mathrm{de}$ \\
\hline BAW-1202 & $2.14 \mathrm{~cd}$ & $2.16 \mathrm{bcd}$ & $1.64 e$ \\
\hline BAW-1182 & $2.51 \mathrm{ab}$ & $2.21 \mathrm{bc}$ & $1.68 e$ \\
\hline BARI Gom-27 & $2.24 \mathrm{bc}$ & 1.60 ef & $1.25 \mathrm{f}$ \\
\hline Level of Significance & \multicolumn{3}{|c|}{ *** } \\
\hline CV (\%) & \multicolumn{3}{|c|}{5.63} \\
\hline
\end{tabular}

Means followed by the same letter(s) did not differ significantly at the 5\% level by the MSTATC program.

** Significant at the $1 \%$ probability level

\section{0-grain weight}

The 1000-grain weight at different growing conditions is presented in Table 7. From the results, it was observed that 1000-grain weight was significantly influenced by growing conditions. In the case of growing conditions, normal growing conditions showed the highest 1000-grain weight $(48.11 \mathrm{~g})$ and moderate heat stress showed medium 1000-grain weight $(40.82 \mathrm{~g})$, whereas severe heat stress showed the lowest 1000-grain weight (36.32 g). Delayed sowing shortened the duration of each developmental phase, which ultimately reduces the grain filling period and lowers the grain weight (Spinks et al., 2004).

The 1000-grain weight of four wheat genotypes is presented in Table 7. From the results it was observed that 1000-grain weight was significantly influenced by wheat genotypes but the combined effect was insignificant. Irrespective of genotypes, BAW-1202 showed the maximum 1000-grain weight $(46.82 \mathrm{~g})$, which was statistically similar to BARI Gom-26 (43.51 g) and BARI Gom-27 showed the lowest 1000-grain weight (35.03 g). Again, BAW-1182 (41.65 g) was moderate in weight and statistically similar to BARI Gom-26 (43.51 g). Reduced grain size under heat stress conditions might be due to the rapid reduction in grain growth duration. The net effect of heat stress in the grain filling period was lower grain weight due to the reduction in grain filling period, grain filling rate or combined effect of both (Tashiro and Wardlaw, 1989).

Table 7. Effect of late seeding warmer condition and genotypes on grains spike $e^{-1}$ and 1000grain wt.

\begin{tabular}{lcc}
\hline \multicolumn{1}{c}{ Treatments } & Grains spike $^{-1}$ (no.) & 1000-grain wt. (g) \\
\hline Growing conditions & & \\
Normal & $50.20 \mathrm{a}$ & $48.11 \mathrm{a}$ \\
Moderate heat stress & $49.14 \mathrm{a}$ & $40.82 \mathrm{~b}$ \\
Severe heat stress & $42.32 \mathrm{~b}$ & $36.32 \mathrm{c}$ \\
\hline Level of Significance & $* *$ & $* *$ \\
CV (\%) & 5.71 & 6.63 \\
\hline Genotypes & & \\
BARI Gom-26 & $54.80 \mathrm{a}$ & $43.51 \mathrm{ab}$ \\
BAW-1202 & $40.78 \mathrm{c}$ & $46.82 \mathrm{a}$ \\
BAW-1182 & $49.00 \mathrm{~b}$ & $41.65 \mathrm{~b}$ \\
BARI Gom-27 & $44.30 \mathrm{bc}$ & $35.03 \mathrm{c}$ \\
\hline Level of Significance & $* *$ & $* 62$ \\
CV (\%) & 7.61 & 8.52 \\
\hline
\end{tabular}

Means followed by the same letter(s) did not differ significantly at the 5\% level by the MSTATC program.

** Significant at the $1 \%$ probability level 


\section{Grain yield}

The grain yield of four wheat genotypes at different growing conditions is presented in Table 8 . Results showed that the interaction effect of growing conditions and wheat genotypes on grain yield was significant. At normal growing conditions, BARI Gom-26 produced the maximum grain yield (361.0 $\left.\mathrm{g} \mathrm{m}^{-2}\right)$, which was statistically similar to BARI Gom-27 (315.7 $\left.\mathrm{g} \mathrm{m}^{-2}\right)$. BARI Gom-27 also statistically similar to BAW-1202 $\left(285.7 \mathrm{~g} \mathrm{~m}^{-2}\right)$ whereas BAW-1182 $\left(242.7 \mathrm{~g} \mathrm{~m}^{-2}\right)$ gave the lowest grain yield which was identical to BAW-1202 $\left(285.7 \mathrm{~g} \mathrm{~m}^{-2}\right)$. Under moderate heat stress conditions, BAW-1202 $\left(270.0 \mathrm{~g} \mathrm{~m}^{-2}\right)$ attained the maximum grain yield, which was statistically similar to BAW-1182 (254.7 $\left.\mathrm{g} \mathrm{m}^{-2}\right)$, BARI Gom-27 $\left(227.7 \mathrm{~g} \mathrm{~m}^{-2}\right)$ and BARI Gom-26 $\left(226.3 \mathrm{~g} \mathrm{~m}^{-2}\right)$. Under severe heat stress condition, BAW-1202 $\left(202.0 \mathrm{~g} \mathrm{~m}^{-2}\right)$ gave the maximum grain yield, which was statistically similar to BAW-1182 (181.0 g m-2) and BARI Gom-27 (152.3 $\mathrm{g} \mathrm{m}^{-2}$ ). BARI Gom-26 (140.0 $\left.\mathrm{g} \mathrm{m}^{-2}\right)$ showed the lowest grain yield, which was statistically similar to BAW-1182 (181.0 $\left.\mathrm{g} \mathrm{m}^{-2}\right)$ and BARI Gom-27 $\left(152.3 \mathrm{~g} \mathrm{~m}^{-2}\right)$. Results from other studies showed that in the case of late sowing, climate and soil moisture were unfavorable (high temperature, low relative humidity in the air and low soil moisture) for crop production, which ultimately affected crop growth and yield (Hossain et al., 2012d; Hossain et al., 2013). In subtropical climates like Bangladesh, excess radiation and high temperatures are often the most limiting factors affecting plant growth and final grain yield (Wahid et al., 2007; Hossain et al., 2009; Nahar et al., 2010; Hossain et al., 2011; Sikder, 2011; Hakim et al., 2012).

\section{Biological yield}

The biological yield of four wheat genotypes at different growing conditions is presented in Table 9. Results showed that the interaction effect of growing conditions and wheat genotypes on biological yield was significant. At normal growing conditions, BAW-1182 attained the highest biological yield $\left(1701 \mathrm{~g} \mathrm{~m}^{-2}\right)$. BARI Gom-26 showed moderate biological yield $(1313 \mathrm{~g}$ $\left.\mathrm{m}^{-2}\right)$, which was statistically similar to BAW-1202 (1299 $\left.\mathrm{g} \mathrm{m}^{-2}\right)$. BARI Gom-27 showed the lowest value of biological yield $\left(1178 \mathrm{~g} \mathrm{~m}^{-2}\right)$. Under moderate heat stress condition, BAW-1182 $\left(1397 \mathrm{~g} \mathrm{~m}^{-2}\right.$ ) attained the highest biological yield while BARI Gom-26 showed the lowest (1006 $\mathrm{g} \mathrm{m}^{-2}$ ) which was statistically similar to BARI Gom-27 (1035 $\left.\mathrm{g} \mathrm{m}^{-2}\right)$ and BAW-1202 (1064 $\left.\mathrm{g} \mathrm{m}^{-2}\right)$. Under severe heat stress conditions, BARI Gom-27 $\left(808.7 \mathrm{~g} \mathrm{~m}^{-2}\right)$ attained the highest biological yield. BAW-1182 (705.3 $\left.\mathrm{g} \mathrm{m}^{-2}\right)$ showed a moderate value which was statistically similar to BAW-1202 (625.3 g m-2). BARI Gom-26 $\left(538.0 \mathrm{~g} \mathrm{~m}^{-2}\right)$ showed the lowest biological yield which was similar to BAW-1202 (625.3 $\left.\mathrm{g} \mathrm{m}^{-2}\right)$. Hossain et al. (2012c) and Hossain et al. (2012d) noticed that when wheat was grown from sowing to maturity at high temperatures, phenological development was rapid, leading to poor biomass production and consequently poor biological yield.

Table 8. Effect of late seeding warmer condition and wheat genotypes on grain yield

\begin{tabular}{lccc}
\hline \multirow{2}{*}{ Genotypes } & \multicolumn{3}{c}{ Grain yield $\left(\mathbf{g ~ m}^{-2}\right)$} \\
\cline { 2 - 4 } & Normal & Moderate heat stress & Severe heat stress \\
\cline { 2 - 4 } & $361.0 \mathrm{a}$ & $226.3 \mathrm{def}$ & $140.0 \mathrm{~h}$ \\
BARI Gom-26 & $285.7 \mathrm{bc}$ & $270.0 \mathrm{bcd}$ & $202.0 \mathrm{efg}$ \\
BAW-1202 & $242.7 \mathrm{cde}$ & $254.7 \mathrm{~cd}$ & $181.0 \mathrm{fgh}$ \\
BAW-1182 & $315.7 \mathrm{ab}$ & $227.7 \mathrm{def}$ & $152.3 \mathrm{gh}$ \\
BARI Gom-27 & & $* * *$ \\
Level of Significance & & 6.89 & \\
CV (\%) & & & \\
\hline
\end{tabular}

Means followed by the same letter(s) did not differ significantly at the $5 \%$ level by the MSTATC program.

* Significant at the $1 \%$ probability level 
Table 9. Effect of late seeding warmer condition and wheat genotypes on biological yield

\begin{tabular}{lccc}
\hline \multirow{2}{*}{ Genotypes } & \multicolumn{3}{c}{ Biological yield $\left(\mathrm{g} \mathrm{m} \mathrm{m}^{-2}\right)$} \\
\cline { 2 - 4 } & Normal & Moderate heat stress & Severe heat stress \\
\cline { 2 - 4 } & $1313 \mathrm{bc}$ & $1006 \mathrm{e}$ & $538.0 \mathrm{~h}$ \\
BARI Gom-26 & $1299 \mathrm{c}$ & $1064 \mathrm{e}$ & $625.3 \mathrm{gh}$ \\
BAW-1202 & $1701 \mathrm{a}$ & $1397 \mathrm{~b}$ & $705.3 \mathrm{~g}$ \\
BAW-1182 & $1178 \mathrm{~d}$ & $1035 \mathrm{e}$ & $808.7 \mathrm{f}$ \\
BARI Gom-27 & & $* *$ \\
Level of Significance & & 2.87 & \\
CV (\%) & & & \\
\hline
\end{tabular}

Means followed by the same letter(s) did not differ significantly at the 5\% level by the MSTATC program.

** Significant at the $1 \%$ probability level

\section{Heat susceptibility index (HSI)}

Heat susceptibility index (HSI) based on grain yield varied in different wheat genotypes both at moderate and severe heat stress conditions. A lower susceptibility index indicates higher tolerance. According to heat susceptibility index, the order of tolerance was BAW-1182 $(-0.26)>$ BAW-1202 (0.26)>BARI Gom-27 (1.47)>BARI Gom-26 (1.95) under moderate heat stress condition and BAW-1182 (0.57)>BAW-1202 (0.66)>BARI Gom-27 (1.18)>BARI Gom26 (1.39) under severe stress condition. Hossain and Teixeira de Silva (2012a) and Hossain et al. (2012b) stated HSI to be a measure of yield stability. Therefore, a stress-tolerant genotype as defined by HSI needs not necessarily to have a high yield potential. The ideal wheat genotype should be high yielding under any environmental conditions.

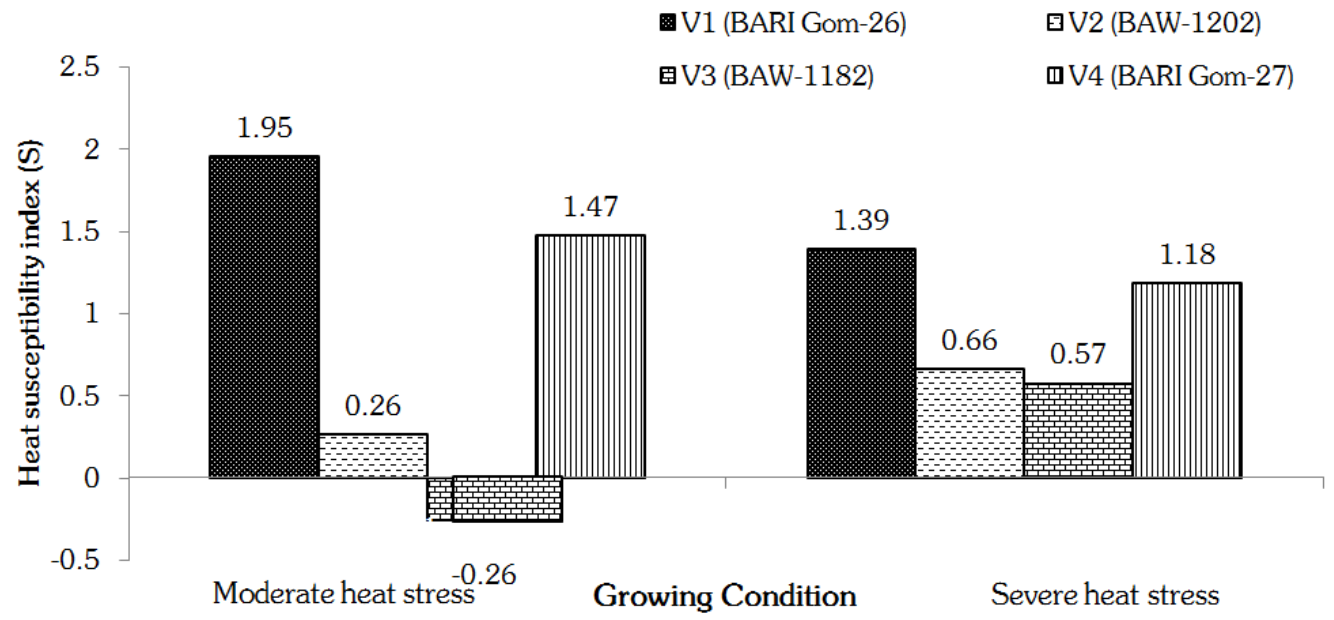

Fig. 4. Heat susceptibility index of different wheat genotypes based on grain yield $\left(\mathrm{g} / \mathrm{m}^{2}\right)$ at moderate and severe heat stress.

\section{Conclusion}

Wheat genotypes BAW-1182 and BAW-1202 showed greater thermostability of cell membrane under heat stress conditions and came out with potential yield harvest. However, based on the heat susceptibility index for grain yield (under moderate and severe heat stress), BAW-1182 was found as most tolerant. 


\section{References}

Al-Khatib, K. and G.M. Paulsen. 1984. Mode of high temperature injury to wheat during grain development. Physiol. Plant. 61: 363-368.

Amrawat, T., N.S. Solanki, S.K. Sharma, D.K. Jajoria and M.L. Dotaniya. 2013. Phenology growth and yield of wheat in relation to agrometeorogical indices under different sowing dates. African J. Agric. Res. 8(49): 6366-6374.

Badruddin, M., D.A. Saunders, A.B. Siddique, M.A. Hossain, M.O. Ahmed, M.M. Rahman and S. Parveen. 1994. Determining yield constraints for wheat production in Bangladesh. In: Saunders D.A. and G.P. Hettel, editors. Wheat in heat stressed environments: irrigated, dry areas and rice-wheat farming systems. CIMMYT, Mexico.pp.265-71.

Behl, R.K., H.S. Nainawatee and K.P. Singh. 1993. High temperature tolerance in wheat. In: International Crop Science, Crop Science Society of America, USA. pp.349-355.

Blum, A. and A. Embercon. 1981. Cell membrane stability as a measure of drought and heat tolerance in wheat. Crop Sci. 21: 43- 47.

CIMMYT. 1995. CIMMYT/NARS Consultancy on ME: Bread Wheat Breeding. Wheat Special Report No. 38. CIMMYT, Mexico, DF.

DEFRA. 2005. India-UK collaboration on impacts of climate change in India.

Dias, A.S., A.S. Baullo and Fe Lindon. 2009. Ultrastructure and biochemical traits of bread and durum wheat grains under heat stress. Brazil J. Plant Physiol. 20: 223-233.

Din, R., G. Subhani, N. Ahmad, M. Hussain and A. Rehman. 2010. Effect of temperature on development and grain formation in spring wheat. Pak. J. Bot. 42: 899- 06.

Falaki, A.M., S. Miko, I.B. Mohammed, I.U. Abubakar and J.A. Valencia. 2009. Evaluation of some improved bread wheat varieties at Chiyako, Jigawa State, Nigeria. ARPN J. Agric. Biol. Sci. 4(4): 1-4.

Farooq, M., H. Bramley, J.A. Palta and K.H.M. Siddique. 2011. Heat stress in wheat during reproductive and grain-filling phases. Crit. Rev. Plant Sci. 30: 1-17.

Fischer, R.A. and R. Maurer. 1978. Drought resistance in spring wheat (Triticum aestivum L.) cultivars. I. Grain yield response. Aust. J. Agric. Res. 29: 897-912.

Fokar, M., A. Blum and H.T. Nguyen. 1998. Heat tolerance in spring wheat. II Grain filling. Euphytica. 104: 9-15.

Hakim, M.A., A. Hossain, J.A.T. Silva, V.P. Zvolinsky and M.M. Khan. 2012. Yield, protein and starch content of twenty wheat (Triticum aestivum L.) genotypes exposed to high temperature under late sowing conditions. J. Sci. Res. 4(2): 477-489.

Hasan, M.A., J.U. Ahmed, M.M. Bahadur, M.M. Hoque and S. Sikder. 2007. Effect of late planting heat stress on membrane thermostability, proline content and heat susceptibility index of different wheat cultivars. J. Natn. Sci. Foundation Sri Lanka. 35(2): 109-117.

Hossain, A. and J.A. Teixeira da Silva. 2012a. Phenology, growth and yield of three wheat (Triticum aestivum L.) varieties as affected by high temperature stress. Not. Sci. Biol. 4(3): 97-106.

Hossain, A., J.A. Teixeira da Silva, M.V. Lozovskaya and V.P. Zvolinsky. 2012c. The effect of high temperature stress on the phenology, growth and yield of five wheat (Triticum aestivum L.) genotypes. Asian Australian J. Plant Sci. Biotech. 6(1): 14-23.

Hossain, A., J.A. Teixeira da Silva, M.V. Lozovskaya, V.P. Zvolinsky and V.I. Mukhortov. 2012d. High temperature combined with drought affect rainfed spring wheat and barley in southeastern Russia; Yield, relative performance and heat susceptibility index. J. Plant Breed. Crop Sci. 4(11): 184-196. 
Hossain, A., M.A.Z. Sarker, M. Saifuzzaman, J.A. Teixeira da Silva, M.V. Lozovskaya and M.M. Akhter. 2013. Evaluation of growth, yield, relative performance and heat susceptibility of eight wheat (Triticum aestivum L.) genotypes grown under heat stress. Int. J. Plant Prod. 7(3): 615-636.

Hossain, A., M.A.Z. Sarker, M. Saifuzzaman, M.M. Akhter and M.S.N. Mandal. 2009. Effect of sowing dates on yield of wheat varieties and lines developed since 1998. Bangladesh J. Prog. Sci. Tech. 7: 5-8.

Hossain, A., M.A.Z., Sarker, M.A. Hakim, M.V. Lozovskaya and V.P. Zvolinsky. 2011. Effect of temperature on yield and some agronomic characters of spring wheat (Triticum aestivum L.) genotypes. Int. J. Agril. Res. Innov. Tech. 1(1\&2): 44-54.

Hossain, A., M.V. Lozovskaya, V.P. Zvolinsky and J.A. Teixeira da Silva. 2012a. Effect of soil and climatic conditions on yield-related components performance of spring wheat (Triticum aestivum L.) varieties in the northern Bangladesh. Nat. Sci. J. Fund. Appl. Res. 2(39): 7786.

Hossain, A., M.V. Lozovskaya, V.P. Zvolinsky and J.A. Teixeira da Silva. 2012b. Effect of soil and climatic conditions on phenology of spring wheat (Triticum aestivum L.) varieties in the northern Bangladesh. Nat. Sci. J. Fund. Appl. Res. 2 (39): 86-97.

Hossain, M.M., H. Takeda and T. Senboku. 1995. Proline content in Brassica under high temperature stress. Japan Int. Res. Center Agric. Sci. (JIRCAS) J. 2: 87-93.

$\mathrm{Hu}$, Z.H. and S. Rajaram. 1994. Differential responses of bread wheat characters to high temperature. Euphytica. 72: 197-203.

Mohi-Ud-Din, M., M.A. Rahman and J.U. Ahmed. 2007. Changes in SPAD value and soluble carbohydrate concentration during senescence of wheat flag leaf under heat stressed environment. J. Asiat. Soc. Bangladesh Sci. 33(2): 121-130.

Nahar, N., K.U. Ahmed and M. Fujita. 2010. Phenological variation and its relation with yield in several wheat (Triticum aestivum L.) cultivars under normal and late sown mediated heat stress condition. Not. Sci. Biol. 2(3): 51-56.

Qin, D.H., Y.H. Ding and S.W. Wang. 2002. A study of environment change and its impacts in western china. J. Earth Sci. Front. 9: 321-328.

Sikder, S. 2011. Physiological basis of heat tolerance in wheat. LAP LAMBERT Acad. Pub. Germany. pp.1-269.

Spinks, P.Q., H.B. Shaffer, J.B. Iverson and William P. McCord. 2004. Phylogenetic hypotheses for the turtle family Geoemydidae. Mol. Phylogenetics Evol. 32(1): 164-182.

Tashiro, T. and I.F. Wardlaw. 1989. A comparison of the effect of high temperature on grain development in wheat and rice. Ann. Bot. 64: 59-65.

Wahid, A., S. Gelani, M. Ashraf and M.R. Foolad. 2007. Heat tolerance in plants: An overview. Environ. Expt. Bot. 61(3): 199-223.

Zadoks, J.C., T.T. Chang and C.F. Konzak. 1974. A decimal code for the growth stages of cereals. Weed Res., Oxford. 14: 415-421. 